\title{
HARDNESS TESTING AND CHEMICAL COMPOSITION ANALYSIS OF ER2 AND ER2T SERIES EMUS TRACTION TRANSMISSION RUBBER-CORD COUPLING BOLTS
}

\author{
Pavels Gavrilovs, Dmitrijs Gorbachovs \\ Riga Technical University, Latvia \\ pavels.gavrilovs@rtu.lv,dmitriy31@mail.ru
}

\begin{abstract}
The article is dedicated to the problem of broken rubber cord coupling bolts, determined on the basis of the statistics of traction gear failures for the period from 2015 to 2019 based on the results of the AS "Pasažieru vilciens" railway company unplanned repair reports. Due to the large number of unscheduled repairs and the large general downtime of electric motor carriage associated with replacing the broken bolts of the rubber-cord coupling, the question arises of the quality of the M-24 bolts of the rubber-cord coupling of the traction gear. As an object under investigation, we used a broken M-24 bolt for attaching a rubber-cord coupling, taken after unplanned repairs from an ER2 8029-02 EMU motor carriage. The article tested the hardness of the samples, and also determined the chemical composition of the steel. The data obtained were compared with the specification data for steel X-45 according to the requirements of GOST-4543-71. Based on the results of the research, the causes of the failure of the M-24 bolt of the fastening of the rubber-cord coupling of the traction gear are analyzed and the discrepancies of the samples to the requirements of GOST-4543-71. The research process consisted of four stages: the first stage, preparing the sample for research; the second stage, determining the hardness of the metal according to the Brinell scale for measuring the sample hardness using the MIC 10 tool. The results were compared with the bolts manufacturer's specifications; the third stage, determination of the sample steel chemical composition using the PMI Master PRO installation. The data obtained were compared with the new bolts manufacturer's specifications. The data obtained were compared with the new bolts manufacturer's specifications according GOST-4345-71; the fourth stage of the study, drawing the main conclusions and conclusions about the steel used for manufacturing of M-24 bolts for fastening the rubber-cord coupling of the EMUs traction gear.
\end{abstract}

Keywords: carriage, rubber-cord, bolts.

\section{Introduction}

During movement, various static and dynamic loads are transmitted. The influence of the dynamic loads is associated with forces and moments, which are set in motion by the force and tehmoments, which are variables, and also determine the requirements for the movement, speed, movement mode (traction, coast, braking). The intensity of the action of these loads on the running gears of the commuter trains is very high:

- acceleration to a set speed of movement in the area;

- coasting;

- braking to a complete stop.

Dynamic loads are associated with the movement of the crew and railways, which have various heterogeneous structures. If the path structure is heterogeneous, it understands the change in the stiffness of the path along the direction of the motion. Under the action of the shock load (the load due to the short duration) during the movement of electrical wiring in new directions, repeatedly alternating the loads are applied to the bolts of the cord coupling, and as a result of this load, the strength of the material of the bolts decreases [1].

On the Latvian railway, at AS Pasažieru vilciens, one of the main reasons for unplanned repairs of traction gears for the motor carriage of the electric gear of the ER2 and ER2T series [2] is the failure (hall) of the M-24 bolts of the traction gears. Moving bolts are mounted by flanges, mounted on the motor carriages on one side and the shaft of the small gear of the traction gear on the other side [3].

According to Pasažieru vilciens, between 2015 and 2019, 294 cases of unplanned repairs of motor carriages due to traction gear malfunctions were recorded. From these cases, there are 132 bolt assemblies M-24 for attaching the rubber cord coupling [4]. The analysis of the statistical data is shown in Fig. 1. The graph shows the total number of unplanned repairs of the traction gears, compared with the total number of unscheduled repairs of the traction gears due to cracking of the rubber-cord coupling bolts. The total downtime of all motor carriage for the year, when performing an unplanned repair of the traction gears associated with replacing of the bolts of the rubber-cord 
coupling, from the moment the motor carriage was unhooked from the train until the carriage was hooked into the train, amounted to:

- 2015 - 40 days or 960 hours;

- 2016 - 44 days or 1056 hours;

- 2017 - 56 days or 1344 hours;

- 2018 - 55 days or 1320 hours;

- 2019 - 51 days or 1224 hours.

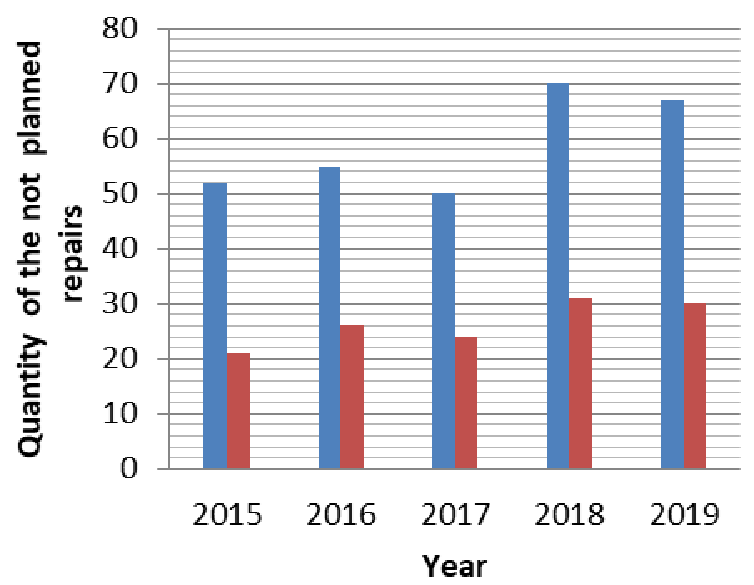

Total quantity traction drives of the not planned repairs

Ammount of damage to the rubber cords bolts

\section{Fig. Number of unplanned repairs in the traction gear and damage to rubber-cord bolts}

\section{Materials and methods}

In this regard, the question arose of what causes the breakage of the rubber-cord coupling bolts?

For these purposes, two bolts were taken, one broken (Fig. 2.1.), the second new (Fig. 2.2), removed from the motor carriage ER2 8029-02. It should be noted that the replacement of the bolts on the ER2 8029-02 carriage was carried out at the TR-3 current repair in September 2018, and in November 2019 one of the 8 rubber-cord coupling bolts broke. It should be noted that the mileage of this carriage from the moment of installation to the kink was $169836 \mathrm{~km}$.

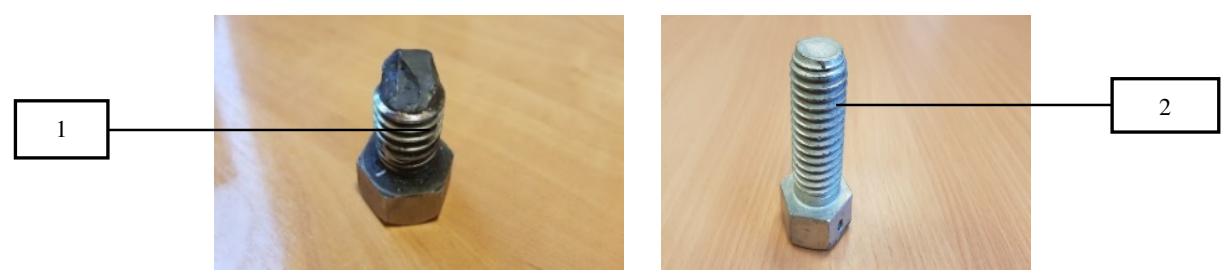

Fig. 2. Rubber-cord bolts, samples M-24: 1 - broken bolt; 2 - new bolt

At the first stage of the study, in order to conduct further research, both broken and new bolts, the surfaces of the bolts were prepared for research. For these purposes, in the laboratory of the Riga Technical University, the upper part of the bolts was cut using a MECATOME T-255/300 cutting machine.

At the second stage of the study, a test was performed in the laboratory of the Riga Technical University for steel hardness, according to the Brinell scale (HB) (Fig. 3- 3.1 - broken bolt; 3.2 - new bolt). The measurements were carried out using the modern instrument "MIC 10" at five points of the crease and the new bolt. The results of the measuring Brinell hardness (HB) are given in Table 1. The results were compared with the data of GOST 4543-71.

Determination of hardness of the bolt

Table 1

\begin{tabular}{|c|c|c|c|c|c|c|}
\hline Measurements & $\mathbf{1}$ & $\mathbf{2}$ & $\mathbf{3}$ & $\mathbf{4}$ & $\mathbf{5}$ & Average \\
\hline HB model hardness 1 & 236 & 234 & 246 & 254 & 276 & 249.2 \\
\hline HB model hardness 2 & 317 & 288 & 287 & 305 & 310 & 301.4 \\
\hline GOST 4543-71 & \multicolumn{7}{|c|}{ Hardness number, HB, maximum X45-229HB. } \\
\hline
\end{tabular}



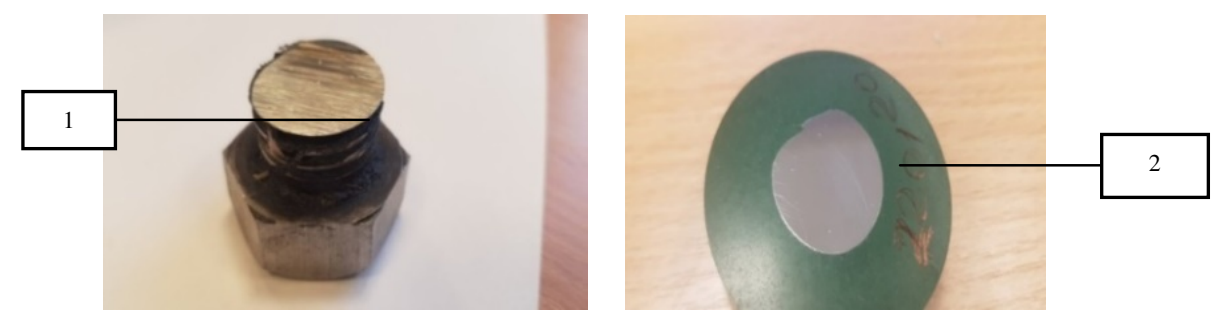

Fig. 3. Determination of the hardness of the bolt: 1 - broken bolt; 2 - new bolt

At the third stage of the study, the chemical composition of the metal of the broken bolt and the new bolt (Fig. 4) were analyzed. To determine the chemical composition of the metal, we used the PMI optical emission analyzer - Master PRO, working on the principle of local burning of the sample surface with subsequent determination of the chemical composition and output of the obtained data to a printing device. The results of the analysis of the chemical composition of the sample are shown in Table 2.
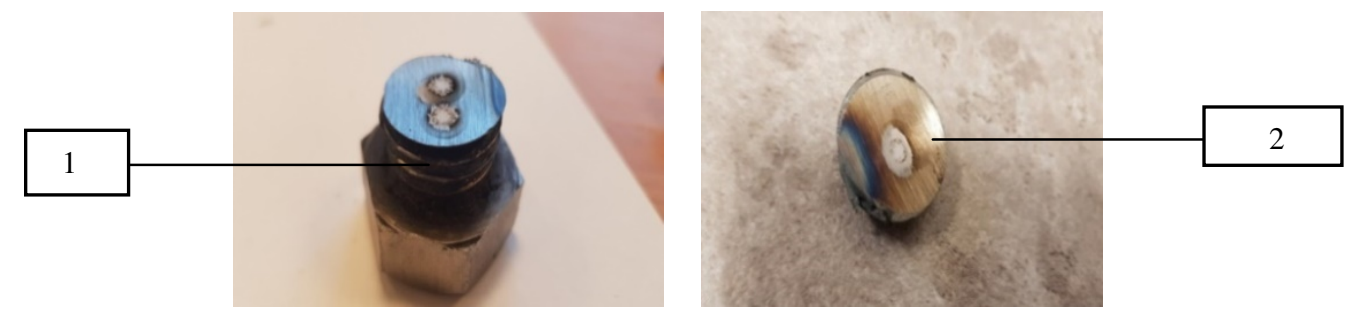

Fig. 4. Determination of the chemical composition of a bolt: 1 - broken bolt; 2 - new bolt

\section{Results and discussion}

According to the results of the chemical analysis, the material grade of the broken bolt corresponds to the steel grade C30E-Sk30, and the new bolt - steel grade 34Cr4. The obtained data of chemical elements were compared with GOST 4543-71. The results of the analysis of the chemical composition of the samples are shown in Table 2.

Table 2

Chemical Analysis of the bolts M-24

\begin{tabular}{|c|c|c|c|c|c|}
\hline \multirow{3}{*}{ Elements } & \multicolumn{4}{|c|}{ Measurements } & \multirow{3}{*}{$\begin{array}{c}\text { GOST 4543-71 } \\
\text { Specification } \\
(X-45)\end{array}$} \\
\hline & \multicolumn{2}{|c|}{ Sample 1 (C30E-Ск-30) } & \multicolumn{2}{|c|}{ Sample 2 (34Cr4) } & \\
\hline & Min/Max & Average & Min/Max & Average & \\
\hline $\mathrm{Fe}$ & ------ & 98.6 & $---\mathbf{- - -}^{-}$ & 97.5 & 98.12-97.24 \\
\hline $\mathrm{C}$ & $0.270 / 0.340$ & 0.316 & $0.300 / 0.370$ & 0.364 & \\
\hline $\mathrm{Si}$ & $0.000 / 0.400$ & 0.229 & $0.000 / 0.400$ & 0.19 & $0.17-0.37$ \\
\hline $\mathrm{Mn}$ & $0.500 / 0.800$ & 0.72 & $0.600 / 0.900$ & 0.603 & $0.50-0.80$ \\
\hline $\mathrm{P}$ & $0.000 / 0.350$ & 0.0098 & $0.000 / 0.350$ & $<0.0050$ & $\begin{array}{ll}----- \\
\end{array}$ \\
\hline $\mathrm{S}$ & $0.000 / 0.350$ & $<0.0050$ & $0.000 / 0.350$ & $<0.0050$ & $\begin{array}{ll}----- \\
-\end{array}$ \\
\hline $\mathrm{Cr}$ & $0.000 / 0.200$ & 0.0377 & $0.9 / 1.2$ & 0.908 & $0.80-1.10$ \\
\hline Mo & $0.000 / 0.100$ & $<0.0030$ & $0.000 / 0.100$ & 0.0071 & $\begin{array}{ll}----- \\
-\end{array}$ \\
\hline $\mathrm{Ni}$ & $0.000 / 0.200$ & 0.0145 & $0.000 / 0.500$ & 0.104 & ------ \\
\hline $\mathrm{Al}$ & $\begin{array}{l}----- \\
\end{array}$ & 0.0090 & $0.000 / 0.100$ & 0.0348 & ------ \\
\hline Co & $0.000 / 0.100$ & 0.0098 & $\begin{array}{ll}----- \\
-\end{array}$ & 0.0150 & ------ \\
\hline $\mathrm{Cu}$ & $0.000 / 0.400$ & 0.0182 & $0.000 / 0.200$ & 0.167 & ------ \\
\hline $\mathrm{Nb}$ & $0.000 / 0.0700$ & $<0.0030$ & $0.000 / 0.0700$ & 0.0037 & ------ \\
\hline $\mathrm{Ti}$ & $0.000 / 0.0700$ & 0.0022 & $0.000 / 0.0700$ & $<0.0020$ & ------ \\
\hline $\mathrm{V}$ & $0.000 / 0.100$ & 0.0044 & $0.000 / 0,070$ & 0.0040 & ------ \\
\hline $\mathrm{W}$ & $0.000 / 0.100$ & $<0.0250$ & $0.000 / 0.100$ & $<0.0250$ & ------ \\
\hline $\mathrm{Pb}$ & $0.000 / 0.0700$ & $<0.0100$ & $0.000 / 0.0500$ & $<0.0100$ & ------ \\
\hline $\mathrm{Zr}$ & ------ & $<0.0030$ & $\begin{array}{ll}----- \\
\end{array}$ & $<0.0030$ & ------ \\
\hline
\end{tabular}


Based on the obtained results, the following conclusions can be drawn, and there are discrepancies with GOST 4543-71, namely [5].

The carbon content $(\mathrm{C})$ is underestimated and amounts to 0.362 for the first sample and 0.364 for the second sample. According to GOST 7543-71, the percentage of carbon should be in the range of $0.41-0.49$.

The chemical element $(\mathrm{Si})$ silicon corresponds to the permissible percentage ratio and is $0.242 \%$ for the first sample and $0.19 \%$ for the second sample. According to GOST 7543-71, the percentage (Si) should be in the range $0.17-0.37 \%$.

The chemical element $(\mathrm{Mn})$ manganese corresponds to the permissible percentage ratio and is $0.74 .8 \%$ for the first sample, $0.603 \%$ for the second sample, according to GOST 7543-71, $0.5-0.8 \%$

Manganese is used to remove oxygen and sulphur from steel. Manganese favourably affects the surface quality over the entire range of carbon content, and also reduces the risk of red breaking [6]. The content of $(\mathrm{Cr})$ chromium in the first sample is underestimated and amounts to $0.047 \%$, instead of $0.8-1.10 \%$, as indicated in GOST 7543-71. In the 2nd sample, the percentage of chromium was $0.908 \%$, which corresponds to GOST 7543-71. Chromium increases the ability of steels to heat harden, their resistance to corrosion and oxidation, provides increased strength at elevated temperatures [7].

\section{Conclusions}

1. The studies made it possible to determine the hardness and chemical composition of steel, to establish the mass fractions of alloying elements included in the structural steel from which the rubber-cord coupling bolts are made.

2. The hardness of the broken and new rubber cord coupling bolt was determined. According to the research results, it was revealed that in the first sample (broken bolt), the average hardness was 249.2 HB, which is 20.2 HB higher than the requirements of GOST 4543-71. The average hardness of the second sample (new bolt) was $301.4 \mathrm{HB}$, which also exceeds the permissible value of GOST 4543-71 by $72.4 \mathrm{HB}$. According to GOST 4543-71, the hardness of the steel should be $229 \mathrm{HB}$. The increased hardness, with a high degree of probability, could affect the specimen crease, since with increased hardness the material of the sample starts to work as brittle, since during the initial inspection of the cracked bolt, traces of delayed brittle fracture, which was under a load close to the yield strength, were found.

3. According to the results of the chemical analysis, the chemical composition of the broken bolt and the new bolt was determined. It was also stated that in this sample there is a small amount of harmful impurities of phosphorus and sulphur, which does not exceed the permissible norm for this steel grade. It should be noted that the chemical elements, both carbon (C) and chromium $(\mathrm{Cr})$, are below the norm and are only 0.361 for carbon for the first sample and 0.366 for the second sample instead of 0.41-0.49, for chromium for the first sample 0.047 is below the norm, instead of 0.80-1.10. As it is known, underestimated carbon content leads to a decrease in the strength of steel, and chromium increases the hardness and strength of steel. It can be assumed that the second reason for the break of the bolt was the low chromium and carbon content, which did not comply with GOST 4543-71.

\section{References}

[1] Межецкий Г.Д., Загребин Г.Г., Решетник Н.Н; под общ. Ред.. Межецкого Г.Д., Загребина Г.Г. Сопротивление материалов (Resistance of materials) 5th edition-Moscow: 2016. 432p. (In Russian).

[2] Рубчинский 3.М., Соколов С.И., Эглон Е.А., Лынюк Л.С., Электропоезда (Electric trains) Moscow: Transport, 1983. 415p. (In Russian).

[3] Цукало П.В., Просвирин Б.К., Эксплуатация электропоездов: Справочник - Москва (Operation of electric trains: Desk-book - Moscow): Transport, 1994. 383p. (In Russian).

[4] Elektrovilcienu neplāna remontu kopsavilkums AS "Pasažieru vilciens" (forma FT-20) (Summary of non-scheduled repairs of electric trains AS "Pasažieru vilciens" (forma FT-20)) (In Latvian).

[5] Structural alloy steel bars Technical Specifications GOST 4543 - 71. 
[6] Никифоров В.М. Технология металлов и других конструкционных материалов (Technology of metals and other structural materials) Moscow: 2015. 384p. (In Russian).

[7] Gavrilovs, P., Dmitrijevs, A. Research in Passenger Car Bogie Central Suspension Roller and Rod Base Metal and Welded Metal Structure. In: 15th International Scientific Conference "Engineering for Rural Development": Proceedings. Vol.15, Latvia, Jelgava, 25-27 May, 2016. Jelgava: 2016, pp.618-623. ISSN 1691-5976. 